\title{
Mastogloia wulffii, a new diatom (Bacillariophyceae) from the west coast of Sweden
}

\author{
Adil Al-Handal ${ }^{* *} \&$ Chiara PenNesi ${ }^{2}$
}

\author{
${ }^{1}$ Department of Biological and Environmental Sciences, University of Gothenburg, Göteborg, Sweden; \\ *Corresponding author email: adil.alhandal@gmail.com \\ ${ }^{2}$ Department of Life and Environmental Sciences, Polytechnic University of the Marche, Via \\ Brecce Bianche, 60131 Ancona, Italy
}

\begin{abstract}
While collecting epiphytic diatom samples from the west coast of Sweden, a small Mastrogloia species has been observed and could not be matched with any of the described taxa. Based on both light and electron microscopes examination, this species has been described as new, Mastogloia wulffii sp. nov. and included in Mastogloia section Sulcatae. This species is very small with valve length not exceeding $16.3 \mu \mathrm{m}$. It is characterized by having a narrow, almost straight median depression on both sides of the sternum-raphe, no marginal ridge and with rounded areolae on valve mantle as well as having completely hyaline lateral sterna. A comparison with similar taxa is given. $M$. wulffii is a marine species growing in moderate numbers on the red alga Polyides rotunda which is widely distributed along the coast of Vrångö Island, Sweden.
\end{abstract}

Key words: Diatoms, Epiphytic, Mastogloia, New species, West coast of Sweden

\section{INTRODUCTION}

Mastogloia Thwaites ex W. Smith is a very diversified diatom genus with more than 410 taxa described from freshwater, brackish and marine habitats (NovARINO 1989). This number has increased remarkably with the description of new species in recent years (e.g. LeE et al. 2014; LobBan \& PenNesi 2014; Pennesi et al. 2011, 2012; 2013; AL-HANDAL \& PenNesi 2015, 2016; Pavlov et al. 2016; Pennesi et al. 2016). High diversity of Mastogloia is most likely attributed to its fast evolution (PADDOCK \& KEMP 1990) which results in wide variation in valve outline and structure. The most striking feature of Mastogloia which separate it from all other naviculoid diatoms, is the presence of one to several hollow chambers on both sides of the internal face of valve margin, these chambers (sensu HustedT 1933) are named partecta and form a structure that runs along the edge of valve margin called partectal ring. Partecta vary in shape, size, orientation and number in the different species and represent a modification of the valvocopula (HUSTEDT 1933, PADOCK \& Kemp 1990, Round et al., 1990; PENNESI et al. 2011). As with other diatom genera which are highly diversified, taxa (mostly marine) of Mastogloia were divided into 10 sections based on ecological and morphological features (HustedT 1933). Another section containing mostly freshwater taxa was added by Simonsen (1990). Morphological similarities between closely related taxa have led to misidentification such as the case of $M$. smithii Thwatis ex W. SMITH and M. lacustris Grunow which were largely confused with each other in the literature (LEE et al. 2014).

Partecta variation in Mastogloia is not the only character to separate species. HustedT (1933) selected several features beside partecta to group Mastogloia into different sections, these include valve outline, stria density, depression on valve face, lateral sterna and others. It became a regular approach to assign a particular Husted's section to any described Mastogloia species.

Marine benthic diatoms in the west coast of Sweden have not been widely investigated and most works were made on the plankton diatoms, mainly as part of environmental monitoring programs (HöGlANDER et al. 2013). Mastogloia does not seem to be widely distributed along the coasts of Sweden and only few species were reported. EDSBAGGE (1968) has recorded 8 species of Mastogloia from the Swedish west coast and none of them were found in large numbers. In the Älv Estuary, not far from the location of the present study, KUYLENSTIERNA (1991) has identified a single species of Mastogloia (M. exigua Lewis) in 75 samples collected over a period of 10 years. On the 
eastern coast of Sweden (Baltic Sea), SnOEJs (1993) recorded 9 species which were mostly brackish water forms. Limited distribution of Mastogloia along coasts of Sweden is attributed to the ecological preference of its species which mostly prefer tropical to subtropical conditions.

In the present study, an epiphytic species of Mastogloia from the west coast of Sweden, in the Gothenburg archipelago, is described as new to science. M. wulffii sp. nov. belongs to Hustedt's section Sulcatae (Hustedt 1933), subgroup 2 (PenNesi et al. 2012). Morphological features and valve ultrastructure are described based on light and scanning electron microscopy. Comparison with other related taxa as well as ecological preference are provided.

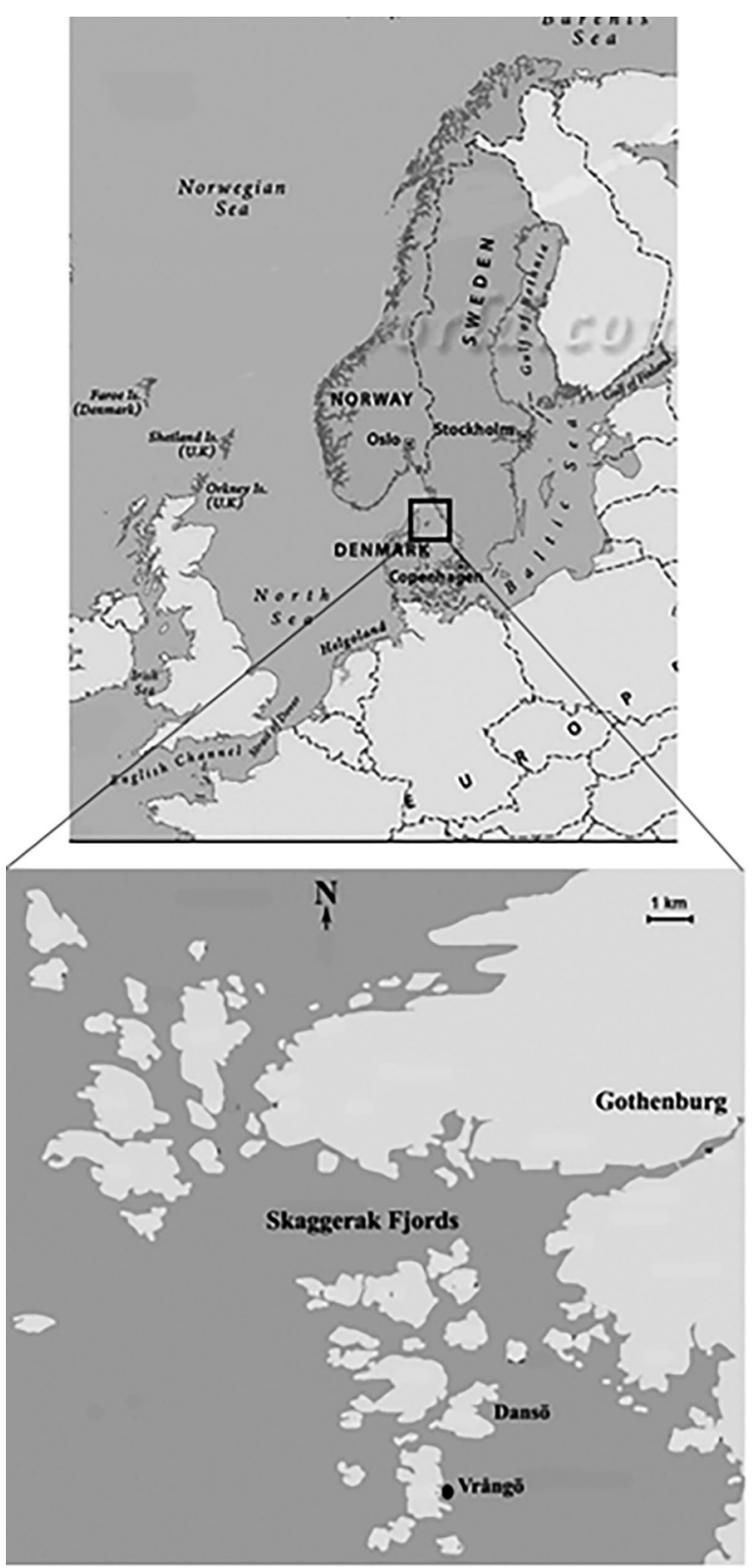

Fig. 1. Map showing sampling location in the west coast of Sweden.

\section{Material ANd Methods}

Samples were collected from Vrångö Island (57 $34^{\prime} \mathrm{N} ; 11^{\circ} 47^{\prime}$ E) which is one of several little islands in the archipelago of the Kattegat strait opposite to the west coast of Sweden (Fig. 1). The Kattegat strait, together with the Skagerrak strait to the north form a connection between the Baltic Sea and the North Sea. Kattegat strait is $220 \mathrm{~km}$ long with a varying width ranging between 60 to $140 \mathrm{~km}$. Brackish water flow from the Baltic Sea lowers salinity in the strait to $30 \mathrm{psu}$, but this value can vary depending on time of the year.

Samples of macrophytes were collected by hand from the eastern coast of Vrångö small island. Macrophytes growing in tidal pools along the intertidal zone and in open water were collected. $M$. wulffi $i$ was found only on the rhodophyte Polyides rotunda (Hudson) GaILlon. In the laboratory, thalli of this macrophyte were shaked vigorously to detach diatoms. Suspension containing diatoms was washed with distilled water from which 20 milliliters were boiled with $35 \%$ hydrogen peroxide for 15 minutes. After cooling, the material was rinsed few times with deionized water. One milliliter of the cleaned material was left to dry on a coverslip in air temperature. Coverslips were left on a hot plate $\left(150{ }^{\circ} \mathrm{C}\right)$ for few minutes to insure that diatom valves adhere to the surface and then inverted on a microscope slide containing small amount of Naphrax ${ }^{\circledR}$ (Brunel Microscopes Ltd., UK), which then heated until all air in the mountant is released to the outside. Light microscope (LM) examination and imaging was made under Zeiss Axioimager 2 microscope with differential interference contrast objectives (Department of Biological and Environmental Sciences, Gothenburg University, Sweden). For scanning electron microscopy (SEM), few drops of the cleaned diatom suspension were left to dry on a black plastic piece adhered to an aluminium stub. When dry, the sample was examined in Hitachi SU8010 SEM (Botanischer Museum, Berlin, Germany). Husted (1933), Paddock and Kemp (1990) and Round (1990) were consulted for the terminology of valve description.

\section{RESULTS}

Polyides rotunda (Gigartinales, Rhodophyta) is a widely distributed macrophyte along the west coast of Sweden (KorNFELDT 1984) and to less extent on the east coast in the Baltic Sea (WALLentinus 1979). Besides Mastogloia wulffii sp. nov., a number of diatom species were found epiphytic on this alga but none was in high numbers. Striatella unipunctata Lyngbye, Tabellaria fenestrate (Lyngbye) Kützing, Cocconeis scutellum Ehrenberg, Cocconeis stauroneiformis (Smith \& Rabenhorst) Okuno and small orbicular forms of Fragillaria Lyngbye were found in moderate numbers. Few other very small unidentified taxa were also observed.

Division Bacillariophyta

Class Bacillariophyceae Haekel

Order Mastogloiales D.G. Mann

Family Mastogloiaceae Mereschkowsky

Genus Mastogloia Thwaites ex W. Smith 
Mastogloia wulffii Al-Handal et Pennesi sp. nov. Light microscopy (LM) (Figs 2-19): Valves elliptical to elliptical-lanceolate with rounded apices and shallow median depression. Apical axis varies from 12.5 to $16.5 \mu \mathrm{m}$, and the transapical axis from 6.5 to $8 \mu \mathrm{m}$ (50 specimens measured). Transapical striae 14-17 in $10 \mu \mathrm{m}$. Raphe branches almost straight. Partectal ring protrudes towards middle of the valve on a siliceous flange. Partecta different in shape with larger size in the middle of the valve, partecta number 3-6 on each side. Scanning electron microscopy (SEM) (Figs 20-31): Valves are elliptical to elliptical-lanceolate (Figs. 2-19 and 20, 23, 26, 31). External valve face: Raphe branches are almost straight (Figs 20,31), ending centrally in slightly expanded pores (Figs 20, 21, 31) and distally in terminal fissures bent toward the same side (Figs 20, 22, 31). Hyaline zones are present on the apices (Figs 20, 22, 31). Valve face shows two distinct zones, one in a shallow narrow and almost straight median depression on both sides of the raphe-sternum not reaching the poles, and an outer zone up to the valve margin (Figs 20, 31). A quadrangular central area is transapically dilated into inner zone (Figs 20, 21, 30, 31). Valve ornamentation consists of transapical striae ranging from straight at the center to slightly radiate at poles (Figs 20, 28, 30, 31). Striation are monoseriate over most of the valve surface and mantle, becoming biseriate near the margins (Figs 28, 29, 31). Areolae are rounded in the outer zone and transapically elongated or quadrangular in the depression and one row of irregular areolae on both sides of the raphe-sternum (Figs 20-22, 31). All areolae are occluded by rotalike velum (Figs 20-22, 30, 31). Internal valve face: Raphe branches are straight and bordered by siliceous ribs, ending centrally in raised slightly expanded pores (Figs 23, 26, 27). Valve surface is characterized by thin hyaline lateral sternum on both sides of the axial area corresponding to the external valve depression; costalike silicified interstriae are visible beyond the inner median zone (Figs 23-27). Partectal ring attached to the valve's margin by a very short siliceous flange (Figs 23). Partecta are unequal (1.3-2.4 $\mu \mathrm{m}$ in width) positioned centrally along each side of the partectal ring (Fig. 23), opening at poles through a lacuna (Fig. 25), septa are visible (Fig. 25, arrowhead). Large partecta (2-2.4 $\mu \mathrm{m}$ in width) are ornamented with tiny pores irregularly arranged in the middle convex margin (Figs 23-25) and open externally through apical partectal pores (Figs 28, 29). Partecta free margin, particularly in the middle, is irregular (Fig. 24).

Holotype: Slide number B 400042019 deposited in the Botanischer Garten und Botanischer Museum (BGBM), Berlin, Germany. The species was found as an epiphyte on the thallus of Polyides rotunda. Figures 14 and 15 represent the holotype (two views of the same valve).

Type locality: Intertidal zone, eastern side of Vrångö
Island, west coast of Gothenburg, Sweden $\left(57^{\circ} 34^{\prime} \mathrm{N}\right.$; $\left.11^{\circ} 47^{\prime} \mathrm{E}\right)$.

Etymology: The epithet is named in honor of our friend and colleague Professor Angela Wulff who has largely contributed to the ecology of diatoms, particularly in polar regions.

\section{Discussion}

Mastogloia wulffii sp. nov. described in this work belongs to HustedT's section Sulcatae (HuSTEDT 1933) based on the presence of a depression on valve face. Recently, Pennesi et al. $(2011,2012)$ revised the genus Mastogloia and divided section Sulcatae into two different subgroups. The first one composed of taxa with siliceous features such as conopea and pseudoconopea on external valve face (subgroup 1, PENNESI et al. 2011), whereas the second subgroup included taxa without these siliceous outgrowths on the valve depression (subgroup 2, PENNESI et al. 2012). It is obvious that $M$. wulffii belongs to the Sulcatae subgroup 2 for the features mentioned above.

Mastogloia wulffii sp. nov exhibits some affinities with two other similar Mastogloia species, $M$. exilis Hustedt and M. sergiana Pennesi et Poulin. $M$. exilis shares similar internal valve face ornamentation, type of partecta and valve outline but differs by its external valve shape. Mastogloia wulffii has narrow, almost straight median depression on both sides of the sternum-raphe while in $M$. exilis the depressions are semi-elliptical and larger (PENNESI et al. 2012). In additional, $M$. exilis shows well-defined marginal ridge runs almost up to the apices and slit-like areolae in the mantle, whereas in $M$. wulffi $i$ there is no marginal ridge and has rounded areolae in the mantle (Fig. 20, 21, 23).

Mastogloia wulffii may also be compared to M. sergiana (PENNESI et al. 2012) which share similar valve outline, type of partecta, type of areolae on the external valve face and similar costa-like silicified interstriae in the internal valve face. However, $M$. sergiana has a thin, well-defined marginal ridge runs up to the apices and a longitudinal rib visible in the depression close to the first row of areolae while in M. wulffii these features are lacking (Fig. 20). Also in $M$. wulffii the median depression is narrow and almost straight while in M. segiana it is semi-elliptical (PENNESI et al. 2012). Furthermore, this new species shows rounded apices and almost straight raphe branches, whereas in $M$. sergiana apices are rostrate and sinuses. Internally, the lateral sterna are thin and interrupted by short striae in $M$. segiana while in $M$. wulffii the lateral sterna are completely hyaline (Figs $24,25,31)$. This new species shows partecta with slightly irregular free margin (Fig. 23), a feature that has not been observed in taxa belonging to the section Sulcatae (Hustedt 1933; PenNesi et al. 2011, 2012). Ecology 

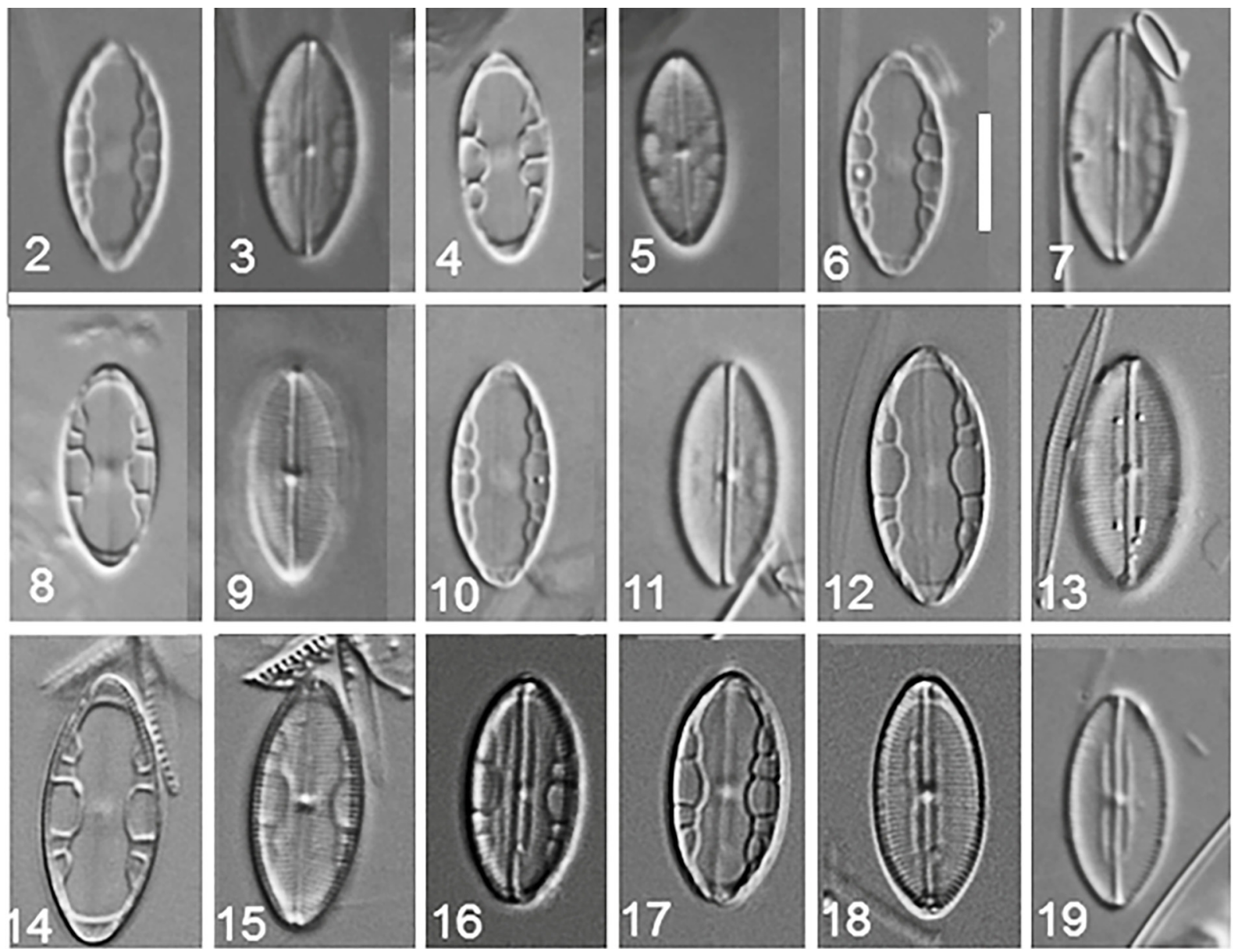

Figs 2-19. Light micrographs of Mastogloia wulffii sp. nov. at different foci showing variable valve size. Scale bars $10 \mu \mathrm{m}$.

M. wulffii is a marine species found as an epiphyte on the rhodophyte Polyides rotunda in the archipelago of the west coast of Gothenburg, Sweden. It occurred in moderate numbers and has not been observed on other macrophytes collected from the same region. It has been previously shown that some diatom species prefer a particular host which narrow their ecological preference (Al-Handal \& Wulff 2008). Salinity in the region varies between 25 to $30 \mathrm{psu}$.

\section{ACKNOWLedgments}

Thanks are due to Mr. Kim Govers and Miss Juliana Bettig of the Botanical Museum, Berlin for their help with SEM observations. The first author is grateful to professor Inger Wallentinius, of the Department of Biological and Environmental Sciences, Gothenburg University for identifying the macrophytes, and to Dr. Regine Jahn of the Botanical Museum, Berlin for hosting and discussions. This research received support from the SYNTHESYS Project http:/ www.synthesys.info/ which is financed by the European Community Research Infrastructure Action under the FP7 "Capacities" Program.

\section{REFERENCES}

Al-Handal, A.Y. \& WulfF, A. (2008). Marine epiphytic diatoms in the shallow sublittoral zone in Potter Cove, King George Island, Antarctica. - Botanica Marina 51:
411-435.

Al-Handal, A.Y., Pennesi C. \& Abdullah D.S. (2015): Two new species of Mastogloia Thwaites ex W. SMith (Bacillariophyceae) from Sawa Lake, Southern Iraq. Fottea 15: 113-122.

Al-Handal, A.Y., Pennesi C. \& Abdullah D.S. (2016): Mastogloia abnormis sp. nov. and Mastogloia descrepata sp. nov. (Bacillariophyceae, Mastogloia section Sulcatae) from Sawa Lake, Southern Iraq. - Diatom Research 31: 113-121. DOI: http://dx.doi.org/10.1080/ 0269249X.2016.1188859

EDSBAGGe, H. (1968): Zur ökologie der marinen angehefteten diatomeen. - Botanica Gothoburgensia 6: 1-139.

GaILlon, B. (1828). Résumé méthodique des classifications des Thalassiophytes. - Dictionnaire des Sciences Naturelles 53: $350-406$

Höglander, H.; Karlson B.; Johansen, M.; Walve, J. \& ANDERsSon, A. 2013. Overview of coastal phytoplankton indicators and their potential use in Swedish waters. - WATERS, Report no. 2013:5. Havsmiljöinstitutet, Sweden, $87 \mathrm{p}$

Hustedt, F. (1933): Die Kieselalgen Deutschlands, Österreichs und der Schweiz unter Berücksichtigung der übrigen Länder Europas sowie der angrenzenden Meeresgebiete. - In: Rabenhorst, L. (ed.): Kryptogamen Flora von Deutschland, Österreich und der Schweiz Vol. 7, Part 2. - pp. 321-432, Akademische Verlagsgesellschaft m.b.h., Leipzig.

KORNFELDT, R.A. (1984): Variation in distribution and biomass of marine benthic algae off Kullen, Sweden. - Nordic 


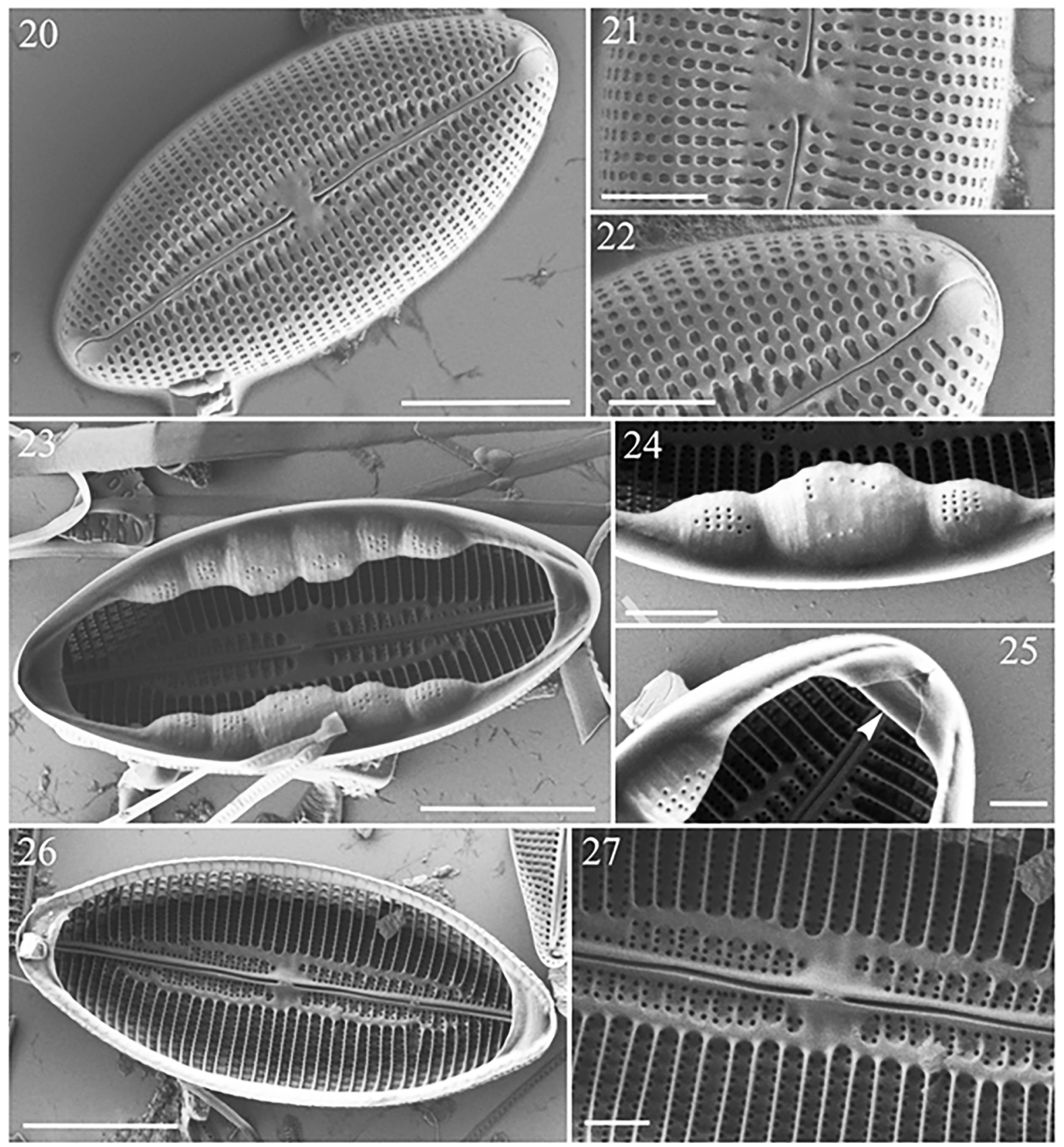

Figs 20-27. Mastogloia wulffii sp. nov., SEM images: (20) External valve view showing shallow median depression and raphe branches; (21) External view of central area and raphe endings; (22) External view of apex showing the bent terminal raphe fissure; (23) Internal valve view showing the partectal ring; (24) Partecta with tiny pores; (25) Apex with lacuna and septum (arrowhead); (26) Internal valve view showing hyaline lateral sterna; (27) Details of the internal central nodule with raised simple pores and interstriae. Scale bars $5 \mu \mathrm{m}(20,23,26), 2 \mu \mathrm{m}$ $(21,22,24), 1 \mu \mathrm{m}(25,27)$.

journal of Botany 4: 563-584.

Kuylenstierna, M. (1991): Benthic algal vegetation in the Nordre Älv Estuary, Swedish west coast [Ph.D. Thesis]. - University of Gothenburg, Sweden.

Lee, S.S.; Gaiser, E.E.; VAn De ViJver, B.; Edlund, M.B. \& SPAUlding, S.A. (2014): Morphology and typification of Mastogloia smithiiand and M. lacustris, with descriptions of two new species from the Florida Everglades and the Caribbean region. - Diatom Research 29: 325-350.

Lobban, C.S. \& Pennesi, C. (2014): Two new Mastogloia species (Bacillariophyceae), M. parlibellioides and M. lyra, from coral reefs in Guam, Western Pacific. - Botanica
Marina 57: 41-54.

Novarino, G. (1989): An update of the taxa of the genus Mastogloia, with a 'resemblance list' for the more recently described ones. - Diatom Research 4: 319-343.

Paddock, T.B. \& K.D. KemP. (1990): An illustrated survey of the morphological features of the diatom genus Mastogloia. - Diatom Research 5: 73-103.

Pavlov, A.; Jovanovska, E.; Wetzel, C.E.; Ector, L. \& Levkov, Z. (2016): Freshwater Mastogloia (Bacillariophyceae) taxa from Macedonia, with a description of the epizoic M. sterijovskii sp. nov. - Diatoms Research 3: 1-28.

Pennesi, C.; Poulin, M. \& TotтI C. (2016): Phylogenetic relationships and biogeography of the diatom genus 

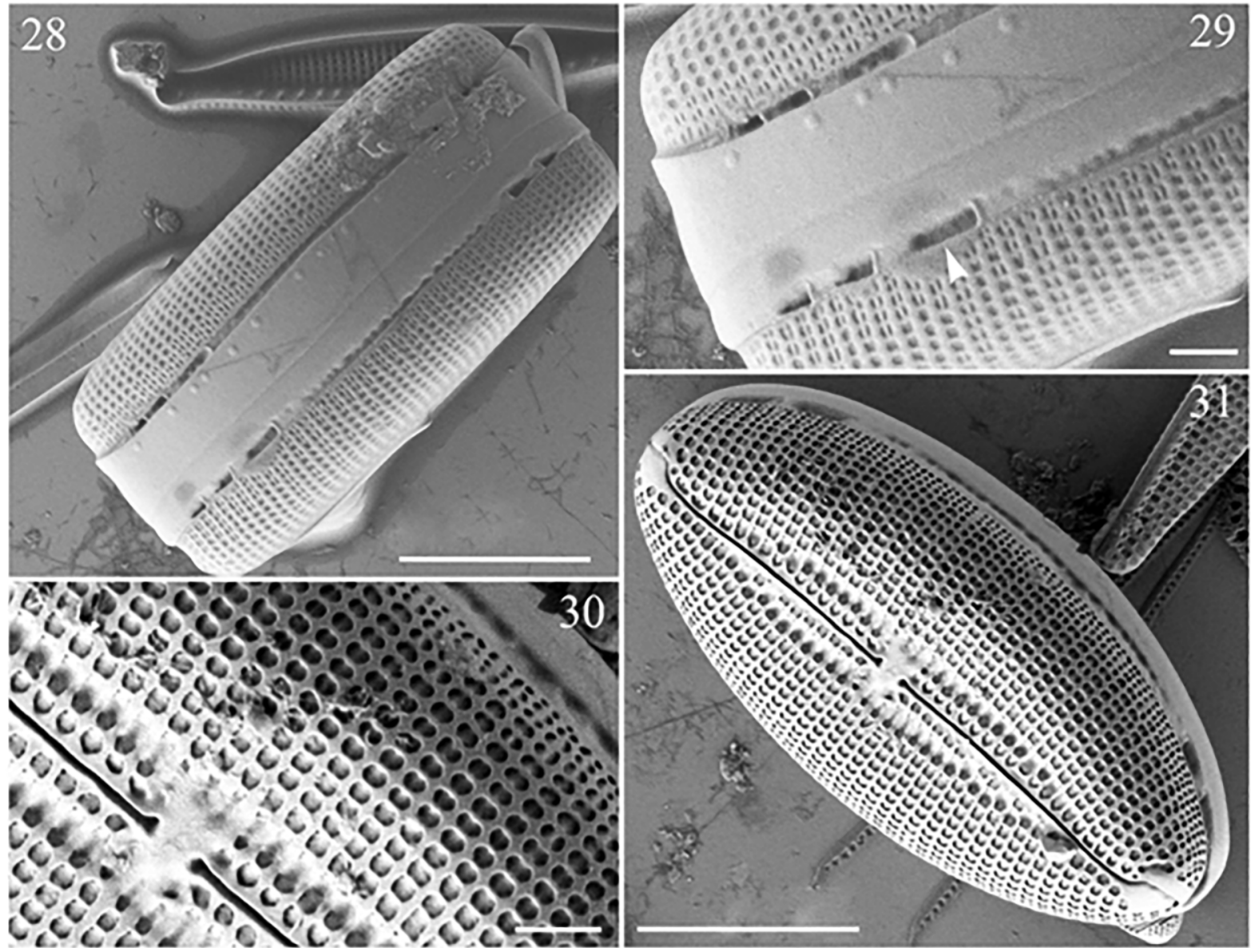

Figs 28-31. Mastogloia wulffii sp. nov., SEM images: (28) Girdle view with partectal pores on the valvocopula; (29) Details on the apex showing partecta pores (arrowhead); (30) External view of areolae; (31) External view of a tilted valve showing median depression. Scale bars $5 \mu \mathrm{m}(28,31), 1 \mu \mathrm{m}(29,30)$.

Mastogloia (Bacillariophyceae): revision of the section Ellipticae including the description of new taxa. Protist 167: 148-173.

Pennesi, C.; Poulin, M.; De Stefano, M.; Romagnoli, T. \& Tотті C. (2011): New insights to the ultrastructure of some marine Mastogloia species section Sulcatae (Bacillariophyceae), including M. neoborneensis sp. nov. - Phycologia 50: $548-562$.

Pennesi, C.; Poulin, M.; De Stefano, M.; Romagnoli, T. \& Tотті C. (2012): Morphological studies of some marine Mastogloia (Bacillariophyceae) belonging to section Sulcatae, including the description of new species. Journal of Phycology 48: 1248-1264.

Pennesi, C.; Poulin, M.; Hinz, F.; De Stefano, M.; Romagnoli, T. \& Tотті C. (2013): Comparison of two new species of Mastogloia (Bacillariophyceae) with other small members of section Ellipticae. - Phytotaxa 126: 1-21.

Pennesi, C.; Poulin, M. \&TotTi, C. (2016): Phylogenetic Relationships and Biogeography of the Diatom Genus Mastogloia (Bacillariophyceae): Revision of the Section Ellipticae Including the Description of New Taxa. Protist 167: 148-173.
SimOnsen, R. (1990): On some diatoms of the genus Mastogloia. - Nova Hedwigia 100: 121-142.

SNoEJs, P. (1993) Intercalibration and distribution of diatom species in the Baltic Sea. - XX pp., Opulus Press, Uppsala, Sweden.

Van De Vijver, B.; Fofana, C.; Sow, E.H.; Cocquyt, C.; Blanco, S. \& Ector, L. (2017): Morphology of two Mastogloia species (Bacillariophyta) from Lac de Guiers, (Senegal) and comparison with the type material of M. braunii Grunow. - European Journal of Taxonomy, In Press.

WALLENTINIUS, I. (1979): Environmental influences on benthic macrovegetation in the Trosa-Askö area, northern Baltic roper. II, the ecology of macroalgae and submersed phanerogams. -Contribution Askö laboratory, University of Stockholm 25:1-210.

(C) Czech Phycological Society (2018)

Received November 2, 2017

Accepted April 4, 2018 